\title{
A geophysical and geochemical interpretation of the configuration of the Mount Peyton complex, central Newfoundland
}

\author{
H.G. Miller and S.A.M. Thakwalakwa \\ Centre for Earth Resources Research and Department of Earth Sciences, \\ Memorial University of Newfoundland, St. John's, Newfoundland A1B 3X7, Canada
}

Date Received May 30, 1991

Date Accepted May 4, 1992

\begin{abstract}
An integrated geophysical, geological and geochemical study of the Mount Peyton complex in central Newfoundland has provided insight into the surface and subsurface configuration of the feature. The geology, magnetics, gravity, copper, nickel and uranium data enable us to delineate and redefine the lithological boundaries of the complex and develop an appreciation of its possible configuration at depth.

The geophysical modelling is consistent with earlier interpretations that the batholith consists of a gabbroic phase which was emplaced in the Botwood Group at $420 \pm 8 \mathrm{Ma}$. A later granitic phase was emplaced at $390 \pm 15 \mathrm{Ma}$. There is a close spatial relationship between the various lithologies and specific geophysical and geochemical signatures.

Shaded relief techniques applied to the aeromagnetic data indicate that the batholith has undergone at least one phase of faulting. Magnetic modelling reveals inward dipping gabbro blocks along the exterior boundaries of the complex. The model derived from the limited gravity data is consistent with the magnetically modelled blocks based on more extensive data.

The geophysical and geochemical data suggest the granitic portion of the batholith is smaller in volume, but larger in area, than implied by the limited outcrop mapping. The geophysical modelling is consistent with a thin granitic phase and thicker gabbroic phase.
\end{abstract}

Une étude géophysique, géologique et géochimique intégrée du complexe du mont Peyton dans le centre de TerreNeuve a fourni des indices sur la configuration de surface et souterraine du complexe. Les données géologiques, magnétiques, gravimétriques et de cuivre, nickel et uranium nous permettent de tracer et de redéfinir les contacts lithologiques du complexe et de développer une appréciation de sa configuration possible en profondeur.

La modélisation géophysique est en accord avec les interprétations antérieures selon lesquelles le batholite comprendrait une phase gabbroïque qui s'est mise en place dans le Groupe de Botwood à $420 \pm 8$ Ma. Une phase granitique plus tardive s'est mise en place à $390 \pm 15 \mathrm{Ma}$. Il y a une association spaciale étroite entre les diverses lithologies et des signatures géophysiques et géochimiques spécifique.

Les techniques de relief ombragé appliquées aux données aéromagnétiques indiquent que le batholite a connu au moins une génération de failles. La modélisation des données magnétiques montre des blocs de gabbro inclinés vers l'intérieur, autour des bordures externes du complexe. Le modèle dérivé de la quantité restreinte de données gravimétriques est en accord avec les blocs de la modélisation magnétique, laquelle est basée sur une plus grande quantité de données.

Les données géophysiques et géochimiques suggèrent que la partie granitique du batholite a un volume plus petit, mais une surface plus grande, que ne l'indiquent les données restreintes de cartographie de surface. La modélisation géophysique est en accord avec une phase granitique mince et une phase gabbroïque plus épaisse

[Traduit par le journal]

\section{INTRODUCTION}

The Mount Peyton batholith or complex (Fig. 1) is prominent on the geological map of Newfoundland (ColmanSadd $e t$ al., 1990) and also on geophysical maps (Williams and Haworth, 1984a,b). The elliptical feature is located in the Exploits Subzone (Williams et al., 1989) of the Dunnage Terrane, and covers an area of $60 \mathrm{~km} \mathrm{x} 30 \mathrm{~km}$.

This paper presents an integrated geological, geochemical and geophysical model, which provides insight on the depth, extent and subsurface distribution of the different lithologies of the Mount Peyton complex. A model for the evolution of the present geometry is proposed.

This study is one of the series of geophysical investigations of specific plutons in Newfoundland in which gravity and/or magnetic data, or both, have been analysed (Miller, 1975; Miller and Pittman, 1982; O'Regan, 1986; Miller, 1988; Miller and Tuach, 1989). The plutons investigated range in age from the Precambrian Holyrood Pluton in the Avalon Terrane (Miller and Pittman, 1982) to the Mesozoic plutons of central Newfoundland in the Exploits Zone (Miller, 1976; O'Regan, 1986). In all studies, a spatial correlation between the plutons and faults at various scales was recognized; similar correspondence has been noted in other areas 


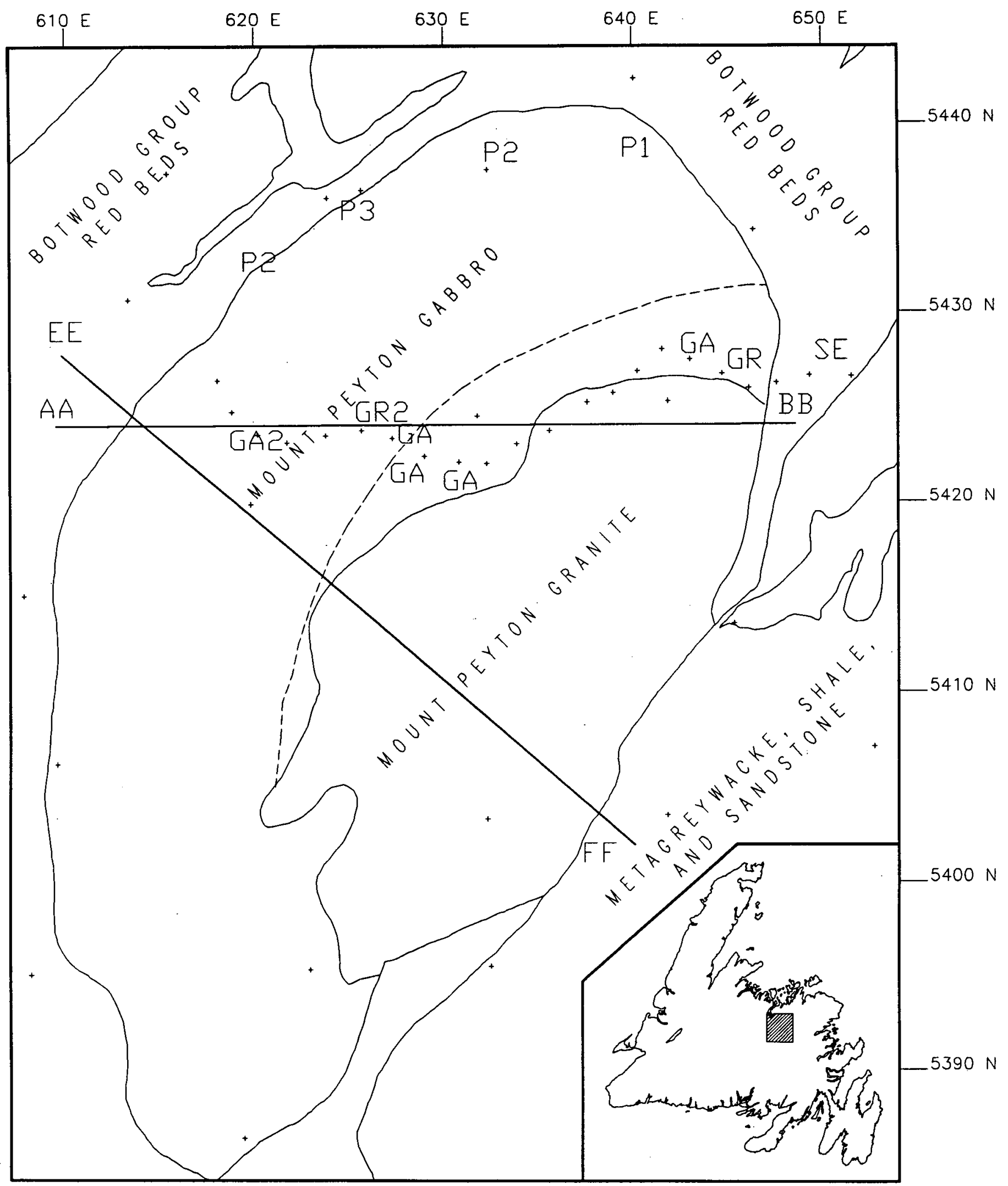

Fig. 1. Simplified geology of the Mount Peyton complex from Strong (1979), Strong and Dupuy (1982) and Blackwood (1982). Coordinates are Zone 21 UTM coordinates in kilometres. Gravity stations are located on this figure and denoted by + . Stations in the area from $620 \mathrm{E}$ to $655 \mathrm{E}$ between $5420 \mathrm{~N}$ and $5430 \mathrm{~N}$ are from our 1989 survey. The others are from Geological Survey of Canada files. Lines AA-BB and EE-FF designate the positions of the modelled profiles; the line of Weaver (1967) coincides with EE-FF. P1, P2, and P3 denote locations of paleomagnetic sampling sites from Lapointe (1979). Numbers indicate the number of samples collected at the site. The symbols GA, GR and SE denote the locations of gabbro, granite and sedimentary samples collected as part of the present study. GR2 denotes two granite samples. Dark lines indicate geological boundaries from the sources listed, dashed line indicates changes to the boundary of the granite interpreted from the data of the present study. 
of eastern North America (Sweeney, 1976; Seguin, 1982a,b; Thomas and Willis, 1989) and in Britain (Leake, 1990).

\section{Geological Setting}

The Mount Peyton complex has been recognized since early reconnaissance mapping was conducted (see Strong, 1979 , for a complete listing of earlier references). The geological map (Fig. 1), compiled from various sources (Strong, 1979; Blackwood, 1982), indicates that the complex is a broad, elliptical, anticlinal feature, overlain on both east and west by Silurian redbeds which are fault bounded locally on the east against Ordovician greywacke and shale of the Gander Group (Blackwood, 1982). On the west the boundary is less well defined; where exposed the complex is conformably overlain by Botwood Group redbeds. This sharp contact shows no evidence of remobilization of the country rocks, thereby providing evidence that the complex intruded after the folding event in the Botwood Group. Most of the complex consists of a gabbroic unit (Mount Peyton Gabbro in Fig. 1) which also contains minor diorite and granodiorite, and comprises more than $70 \%$ of the outcrop area. A granitic unit occupies the remainder. There is no indication in previous studies of the outcrop distribution upon which these spatial estimates are based. Strong (1979) and Strong and Dupuy (1982) interpreted the gabbros as being derived from the upper mantle and the granites as being derived by crustal anatexis due to the intrusion of the gabbroic melt. Their major conclusion was that the granite cannot have been derived from the gabbro by crystal fractionation.

Further evidence for the lack of genetic association between the gabbroic and granitic units is obtained from the paleomagnetic and geochronologic data. Reynolds et al. (1981) established an ${ }^{40} \mathrm{Ar} /{ }^{39} \mathrm{Ar}$ age of $420 \pm 8 \mathrm{Ma}$ for the gabbroic phase; Bell et al. (1977) established a $380 \pm 30 \mathrm{Ma}$ age for the granitic unit which has since been revised to 390 $\pm 15 \mathrm{Ma}$ (Reynolds et al., 1981). A paleomagnetic investigation (Lapointe, 1979) determined different paleopoles for the gabbroic and granitic units, consistent with the geochronology. All the paleomagnetic samples were collected from the primarily gabbroic region of the complex (Fig. 1).

\section{Previous Geophysical Studies}

Weaver (1967) presented the only published interpretation of geophysical data over the Mount Peyton complex in a gravity profile with derived model. He presented, but did not model, the magnetic data along his profile, which approximately coincides over the complex with our EE-FF profile. His gravity model, derived from limited density and gravity control using a density contrast of $+0.10 \mathrm{~g} \mathrm{~cm}^{-1}$ for the gabbro and $-0.09 \mathrm{~g} \mathrm{~cm}^{-3}$ for the granite, depicts the feature as being wedge- or cone-shaped, with a maximum depth of $12 \mathrm{~km}$. On the west side the bottom of the gabbro is inferred to be gently dipping southeastward; on the east side it dips steeply to the northwest. The granite was deduced to be very thin based on its negligible effect on the anomaly pattern. The magnetic profile presented by (Weaver, 1967) is singularly flat, probably as a result of a large digitizing interval. Strong and Dupuy (1982) commented that the feature is an elliptical cone $60 \mathrm{~km}$ by $30 \mathrm{~km}$ with a maximum depth of $12 \mathrm{~km}$ deep. No reference was given for their depth determination but it appears to be taken from Weaver (1967). Apparently, based on these estimates, they concluded that the complex is $95 \%$ gabbro and $5 \%$ granite by volume, with negligible amounts of intermediate compositions. This contrasts markedly with the estimate of $70 \%$ gabbro and $30 \%$ granite based on the areal extent of the outcrop areas.

\section{Present Study}

\section{Magnetics}

The magnetic data were obtained from the Geological Survey of Canada in the form of gridded total magnetic field anomaly values, with a spacing of $812.8 \mathrm{~m}$, from which the appropriate geomagnetic reference field had been removed. The data over the complex were extracted from the larger set and contoured using a gridding interval of $812.8 \mathrm{~m}$ to produce the total magnetic field anomaly map presented in Figure 2.

Magnetic shaded relief maps were produced to enhance features having a particular orientation (Fig. 2). These maps are generated by illuminating the magnetic data, which are treated as topographic elevations, with a light source for which the azimuth and inclination may be varied. The resulting effect is similar to that of the sun shining on the earth's surface, with dark areas in the flank of high anomalies which appear as highly reflective.

\section{Gravity}

Gravity data were obtained from the national gravity data base and by data acquisition specifically for this study. The data from the national base, the original data of Weaver (1967), have a nominal station spacing of $13 \mathrm{~km}$. The new gravity stations were occupied at $2 \mathrm{~km}$ spacing in the northern portion of the complex along the only two logging roads into the complex (Fig. 1). All new data were reduced to Bouguer anomalies using standard Geological Survey of Canada practices, thereby yielding anomalies on the same datum as those from the national data base.

\section{Physical properties}

The quantitative interpretation of potential field data depends on knowledge of the physical properties of the rock units involved. The limited road access, which caused the gravity station distribution to be concentrated along the roads, also resulted in a sparse distribution of samples available for physical property determination. Rock samples were collected from all outcrops encountered during the collection of the new gravity data; the location, density and magnetic susceptibility for these samples are presented in Table 1 and 


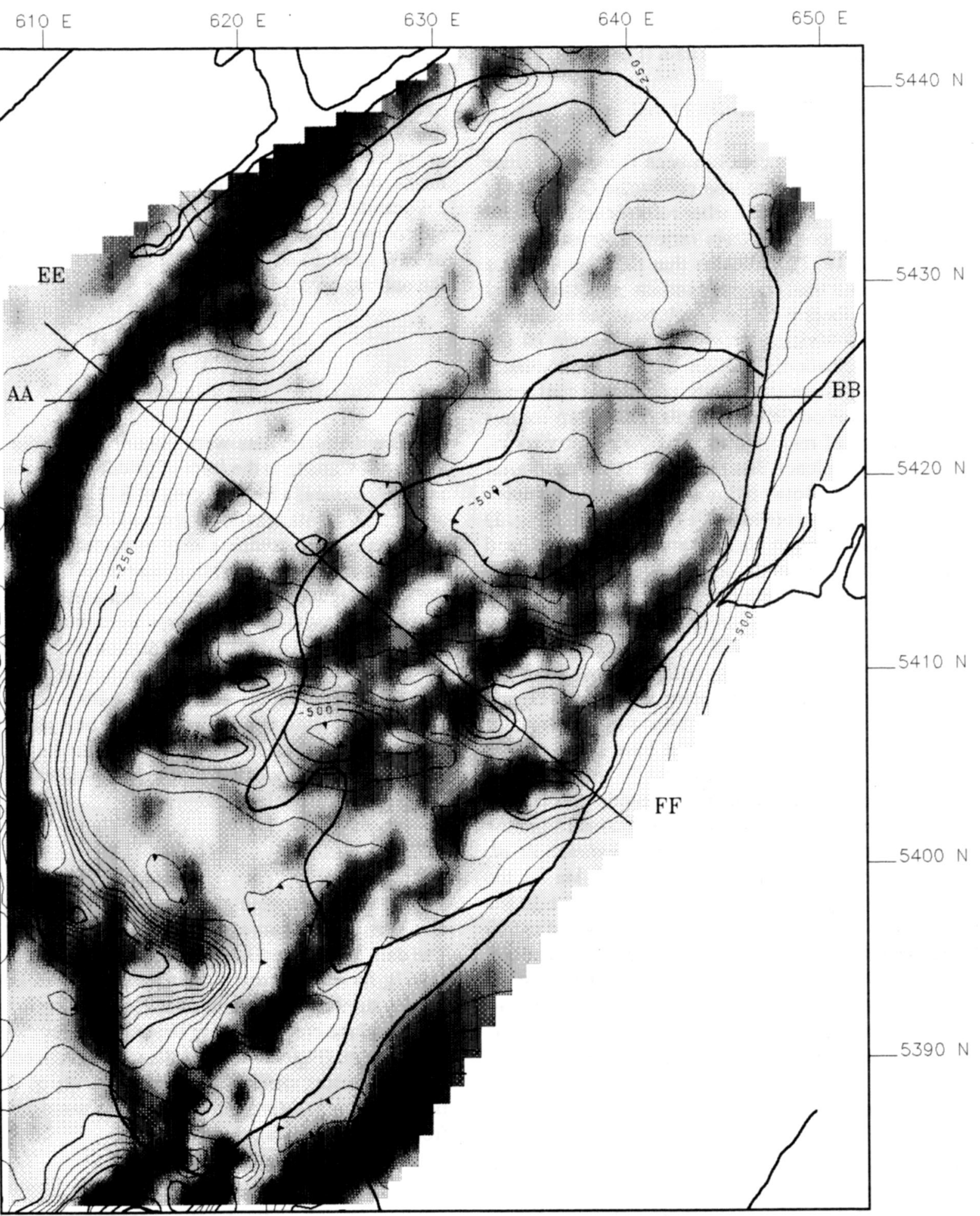

Fig. 2. Magnetic anomaly map for the Mount Peyton complex produced with $0.812 \mathrm{~km}$ gridded data. The coordinates are the same as for Figure 1. Contour interval $50 \mathrm{nT}$. Dark solid lines indicate outlines of major geological units depicted on Figure 1. Grey tone patterns illustrate the shaded relief produced from magnetic data using an illumination from azimuth $115^{\circ}$ with an inclination of $45^{\circ}$ from the horizontal. AA-BB and EE-FF indicate locations of modelled profiles.

the sampling locations and rock types are depicted on Figure 1. No measurements of remanent magnetization were made; previous experience with similar rocks elsewhere in the central Newfoundland area suggests that the induced mag- netization probably substantially dominates the remanence (Miller, 1976). The paleomagnetic data from Lapointe (1979) suggest that the NRM directions are not substantially different from the present field, hence any NRM present will have 
Table 1. Density and magnetic susceptibility.

\begin{tabular}{|c|c|c|c|c|c|}
\hline \multirow{2}{*}{$\begin{array}{c}\text { Sample } \\
\text { No. }\end{array}$} & \multicolumn{2}{|c|}{ Location } & \multirow[b]{2}{*}{ Rock Type } & \multirow{2}{*}{$\begin{array}{l}\text { Density } \\
(\mathrm{g} / \mathrm{cc})\end{array}$} & \multirow{2}{*}{$\begin{array}{r}\text { Magnetic } \\
\text { Suscept. } \\
\left(10^{-3} \mathrm{cgs}\right)\end{array}$} \\
\hline & Easting & Northing & & & \\
\hline 1 & 625.625 & 5423.725 & granite & 2.61 & 0.03 \\
\hline 2 & 643.050 & 5427.475 & gabbro & 2.84 & 0.00 \\
\hline 3 & 646.150 & 5426.000 & granite & 2.5 & 0.00 \\
\hline 4 & 628.975 & 5422.450 & gabbro & 2.79 & 1.20 \\
\hline 5 & 625.625 & 5423.725 & granite & 2.65 & 0.00 \\
\hline 6 & 620.125 & 5423.525 & gabbro & 2.93 & 0.00 \\
\hline 7 & 627.275 & 5423.325 & gabbro & 2.80 & 0.13 \\
\hline 8 & 649.375 & 5426.650 & sediment & 2.71 & 0.00 \\
\hline 9 & 630.775 & 5422.125 & gabbro & 2.84 & 0.00 \\
\hline 10 & 620.125 & 5423.525 & gabbro & 3.36 & 0.00 \\
\hline
\end{tabular}

\begin{tabular}{lllll}
$\begin{array}{l}\text { Rock } \\
\text { Type }\end{array}$ & $\begin{array}{l}\text { Average } \\
\text { Density }\end{array}$ & Range & $\begin{array}{l}\text { Average } \\
\text { Suscept. }\end{array}$ & Range \\
\hline
\end{tabular}

Granite $\quad 2.59 \mathrm{~g} / \mathrm{cc} \quad 2.50-2.650 .01 \times 10^{-3} \mathrm{cgs} \quad 0.00-0.03$

Gabbro $2.93 \mathrm{~g} / \mathrm{cc} \quad 2.80-3.36 \quad 0.22 \times 10^{-3} \mathrm{cgs} \quad 0.00-1.20$

a significant component along the present, or inducing, field and thereby enhance it. The susceptibility needed to model the magnetic response is then a pseudo-susceptibility larger than that measured (Miller, 1976).

\section{Geochemical data}

Variations in the geochemistry of the complex were noted from a regional geochemical study (Strong $e t$ al., 1974), prompting a more detailed study (Strong, 1979; Strong and Dupuy, 1982). More recently, the complex has been sampled with a density of one station per seven square kilometers as part of the lake geochemical sampling programme of the Newfoundland Department of Mines and Energy (Davenport and Nowlan, 1988; Davenport et al., 1988). This resulted in the preparation of separate unpublished studies of the geochemistry and geophysics of the complex (Hayes, personal communication, 1989; Kilfoil, personal communiction, 1989) and a reevaluation of the boundaries of specific lithologies comprising the batholith. The data for copper, nickel and uranium were extracted from this data set and gridded onto a $\mathbf{1 ~} \mathbf{k m}$ grid. The resulting maps are presented in Figures 3, 4, and 5 for nickel, copper and uranium respectively. These elements were chosen to highlight specific rock types, the copper and nickel for ultramafic rocks and the uranium for granite.

\section{QUALITATIVE INTERPRETATION}

\section{Gravity}

The strong positive gravity anomaly of the Mount Peyton complex is a major feature on the gravity map of Newfoundland (Weaver, 1967). It occupies a position between the predominantly positive anomalies of the Dunnage Terrane and the equally strong negative Bouguer anomalies of the Gander Terrane (Miller, 1990). In the area of the complex, the regional field is approximately flat with an amplitude of $0 \mathrm{mGal}$, hence no regional field was removed before modelling. The nature of the gravity field is illustrated in Figure 6 for profile AA-BB. Over the complex the Bouguer anomalies are positive, attaining a maximum anomaly of approximately $+28 \mathrm{mGal}$. The general shape of the gravity anomaly pattern conforms to the outline of the complex, the data outside the complex form a plateau at a minimum of about $3 \mathrm{mGal}$ and then increase rapidly to the northwest on the western boundary; on the eastern side the regional plateau is at the same level just off the complex. Then the anomalies decrease rapidly to the southeast. The density data (Table 1) indicate an appreciable positive density contrast between the gabbro and the sedimentary rocks. The data presented demonstrate that the granite samples, although few in number, have a range of density from $2.5 \mathrm{~g} \mathrm{~cm}^{-3}$ to $2.65 \mathrm{~g} \mathrm{~cm}^{-3}$, consistent with other Newfoundland granites of similar age (Miller and Tuach, 1989). The more mafic rocks typified by the gabbros have densities in excess of $2.80 \mathrm{~g} \mathrm{~cm}^{-3}$, demonstrating that there is a significant difference between the density of the granites and that of the gabbros. The density of the sedimentary rocks, $2.71 \mathrm{~g} \mathrm{~cm}^{-3}$, is typical of sedimentary rocks of similar age and lithology throughout central Newfoundland (Miller, 1970; Weaver, 1967) and is also the average, or background, density for Newfoundland. The granite density is negative relative to this background density, implying that the gravity anomaly over the granitic unit should be negative. The strong positive Bouguer anomaly over all the complex indicates that the contribution of the denser components dominates and that the granite component must be fairly thin.

The generally increasing inward nature of the gravity gradient over both edges of the complex indicates that the body thickens towards the centre. The gentler gravity gradient on the northwest edge, compared with that on the southeast side, suggests a more gentle inward dip to the bottom of the complex on the northwest (Fig. 6).

\section{Magnetic data}

The magnetic patterns over the complex (Figs. 2,6,7) are consistent with generally inward-dipping contacts on the northwestern and southeastern boundaries. The highest magnetic anomalies occur over the boundaries of the complex; lower amplitude anomalies are located in the interior. An east-striking anomaly pattern occurring at approximately $5410 \mathrm{~N}$ and other variable patterns in this area suggest a structural or lithological complexity in the part of the complex mapped as granitic, especially because the granitic rocks are much less magnetic than the gabbros. A northeast-striking fabric is discerned on the shaded relief map produced by illumination with a declination of $115^{\circ}$ (Fig. 2). The most 


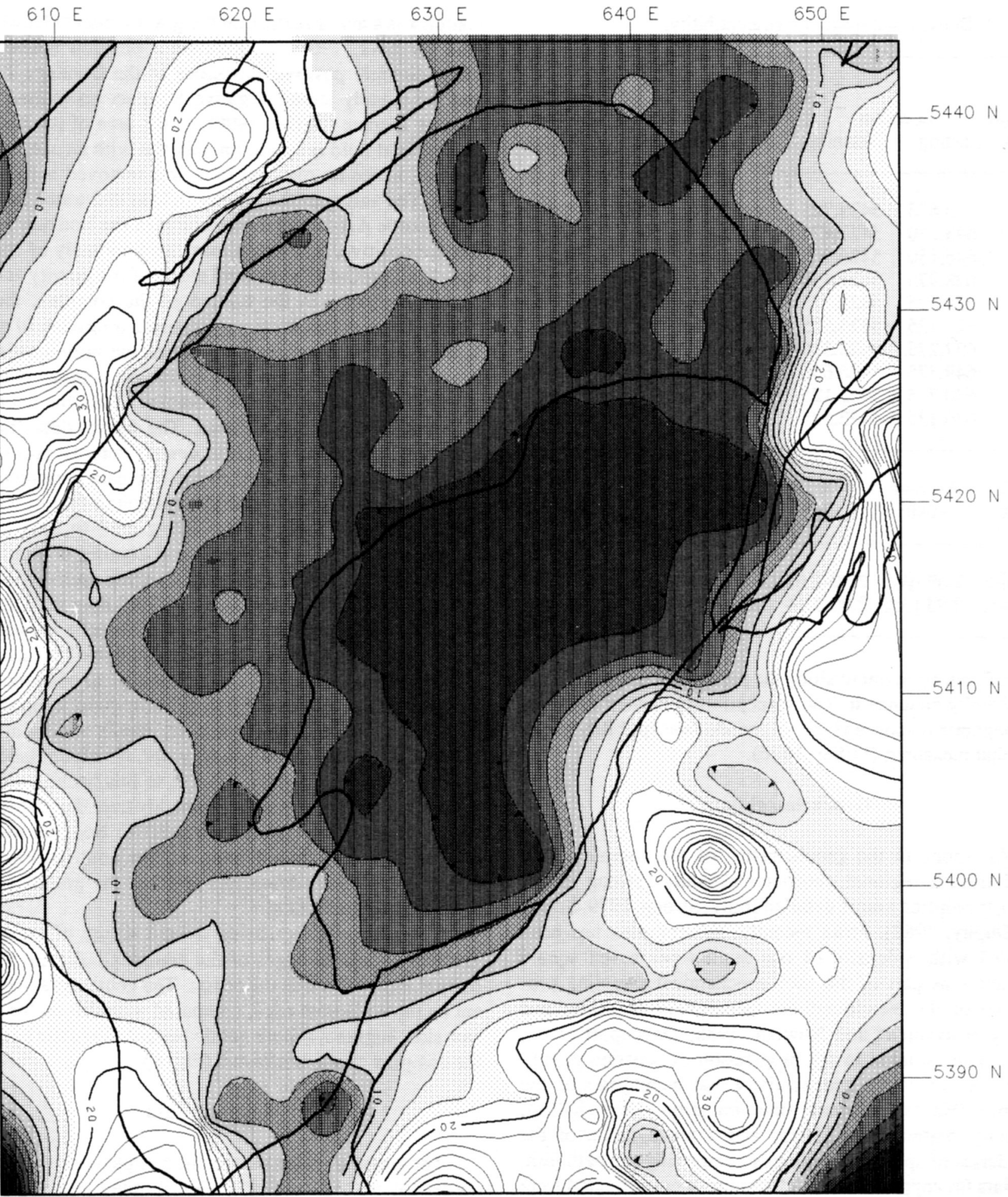

Fig. 3. Contour map of nickel concentrations for the study area, based on data interpolated onto a $1 \mathrm{~km}$ grid. Contour interval is $2 \mathrm{ppm}$. The geological outlines presented are the same as on Figure 2 and the coordinates are the same as on Figure 1.

prominent feature extends from $5440 \mathrm{~N}, 638 \mathrm{E}$ to $5410 \mathrm{~N}, 625$ $\mathrm{E}$; a similar trending feature, which could be an offset, is located from $5405 \mathrm{~N}, 635 \mathrm{E}$ to $5385 \mathrm{~N}, 615 \mathrm{E}$ with the zone of possible offset between $5410 \mathrm{~N}$ and $5415 \mathrm{~N}$.

\section{Geochemistry}

The elements mapped (Figs. 3, 4, 5) were chosen to demonstrate the differences in composition between the 
$610 \mathrm{E} \quad 620 \mathrm{E} \quad 630 \mathrm{E}$

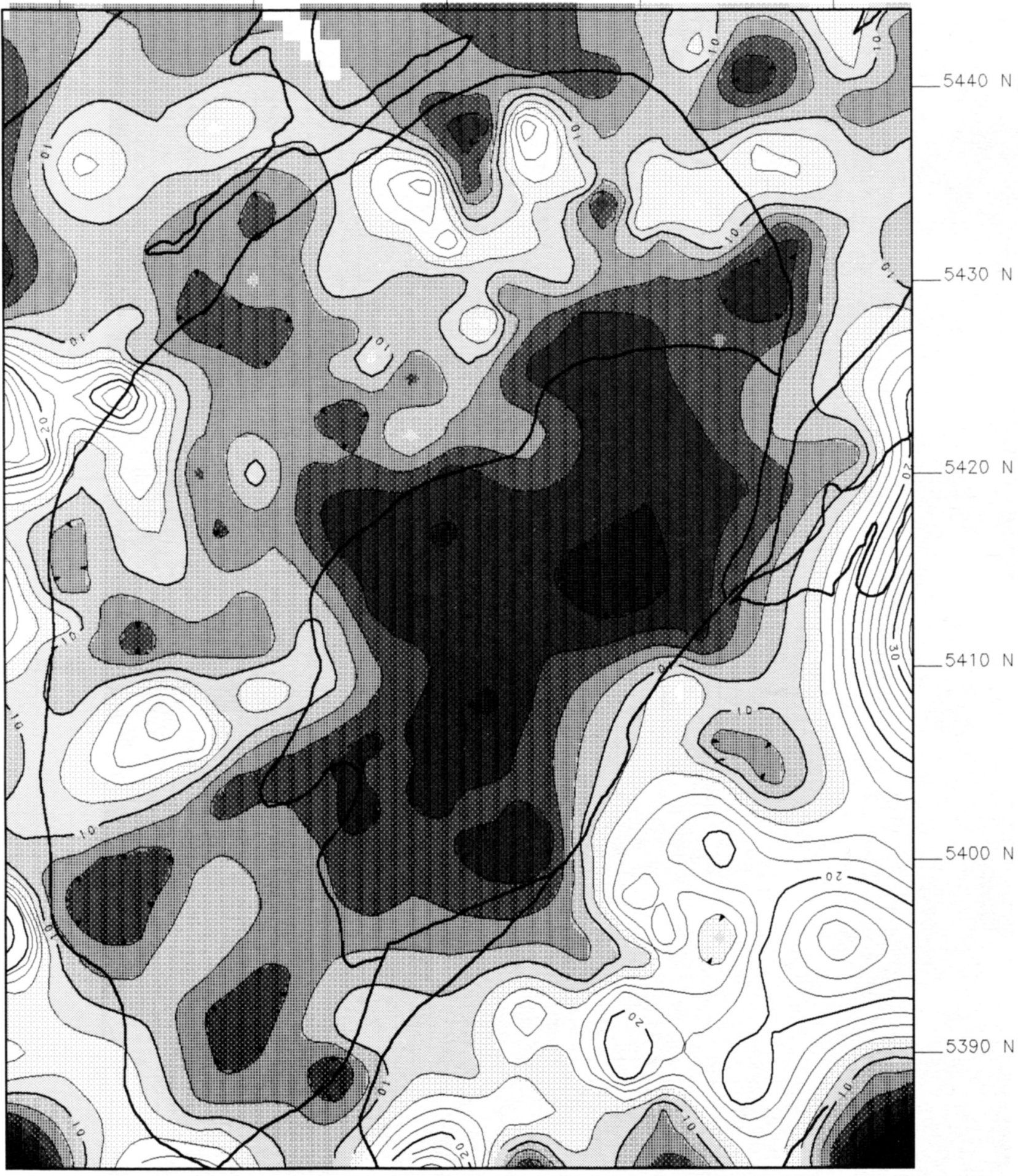

Fig. 4. Contour map of copper concentrations for the study area, based on data interpolated onto a $1 \mathrm{~km}$ grid. Contour interval is 2 ppm. The geological outlines presented are the same as on Figure 2 and the coordinates are the same as on Figure 1.

various portions of the complex. Nickel and copper were selected to highlight the more mafic units and uranium was chosen to delineate the granitic portions. As the data were obtained from lake and stream geochemical sampling programs (Davenport and Nowlan, 1988; Davenport et al., 1988), drainage dispersion effects are expected to be noticeable on the element distribution maps. The maps demonstrate that the complex is depleted in copper and nickel relative to the surrounding areas; the uranium distribution shows greater correlation with the lithologies of the complex. Examination 


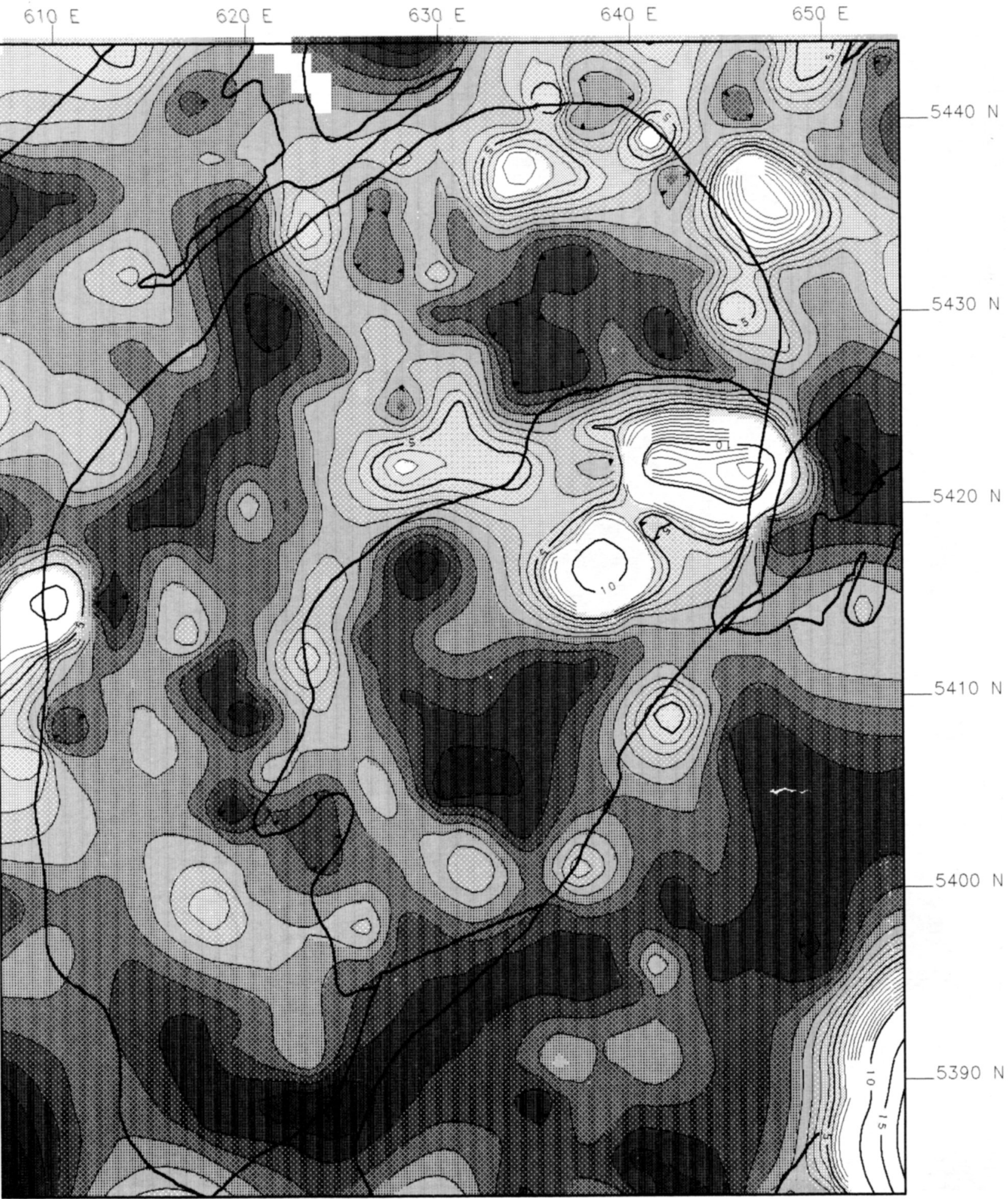

Fig. 5. Contour map of uranium concentrations for the study area based on data interpolated onto a $1 \mathrm{~km}$ grid. Contour interval is 0.5 ppm. The geological outlines presented are the same as on Figure 2 and the coordinates are the same as on Figure 1.

of the drainage patterns in the area suggests that any copper and nickel weathered from the mafic rocks on the northwestern and southeastern edges of the complex would collect in the major adjacent drainage channels. Any uranium produced by the granite would tend to collect in relatively isolated ponds and bogs of the higher elevation portion of the com- plex. The element distribution maps reveal such a pattern.

The uranium plot, Figure 5 , is dominated by a major elliptical area of high values centered at $5420 \mathrm{~N}$, which coincides with a closed minima in nickel and copper. This area also concides with the most negative magnetic anomalies, although the magnetic pattern is disturbed with some 


\section{AA-BB Transect}

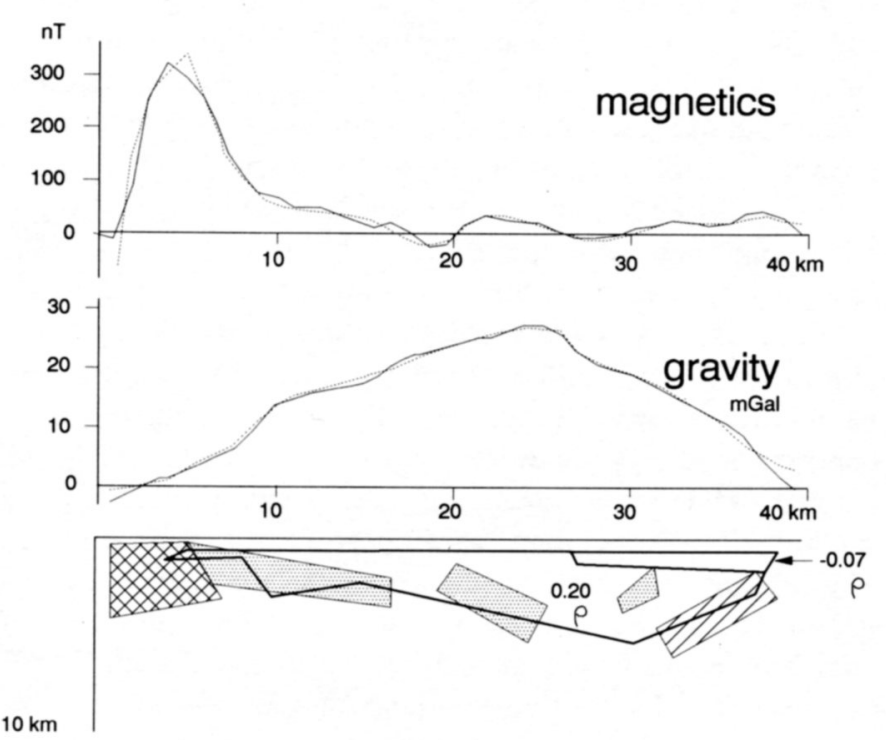

Fig. 6. Modelled data for profile AA-BB. Hatched patterns indicate magnetic bodies with magnetizations in $10^{-3} \mathrm{MKS}$ units as follows:

\section{Range 2.1-2.7 8888 Range 1.2-1.7}

Dark solid lines outline the bodies used in calculating gravity effect. Numbers given in the bodies are the density contrast relative to $2.71 \mathrm{~g} \mathrm{~cm}^{-3}$. On the profiles, solid lines represent the observed data and dashed lines are the calculated effect for the bodies depicted.

\section{localized higher anomalies.}

The general coincidence of these geochemical anomalies, and the low magnetic anomalies with the mapped granitic area, provides some confidence in suggesting that the area in which the granite occurs beneath surface cover may be somewhat larger than originally interpreted from limited outcrop data (Strong, 1979) and may extend as shown in Figure 1. The new boundary, shown by the dashed line in Figure 1, is an amalgamation of the $-400 \mathrm{nT}$ magnetic, the 6 ppm copper, the $5 \mathrm{ppm}$ nickel and $2.5 \mathrm{ppm}$ uranium contours.

\section{Quantitative InTERPRETation}

Modelling was undertaken for two profiles (Fig. 2) chosen: (i) to intersect orthogonally the bounding magnetic high on the northwestern side of the complex and traverse across to the southeast (EE-FF), and (ii) to be coincident with the single gravity transect across the complex (AA-BB). The magnetic data control is denser, hence the magnetic modelling was undertaken first. For profile AA-BB the resulting magnetic model was then used to compute the gravity response of the bodies used in magnetic modelling. The process was iterated until a reasonable fit was obtained to both data sets.

\section{EE-FF Transect}
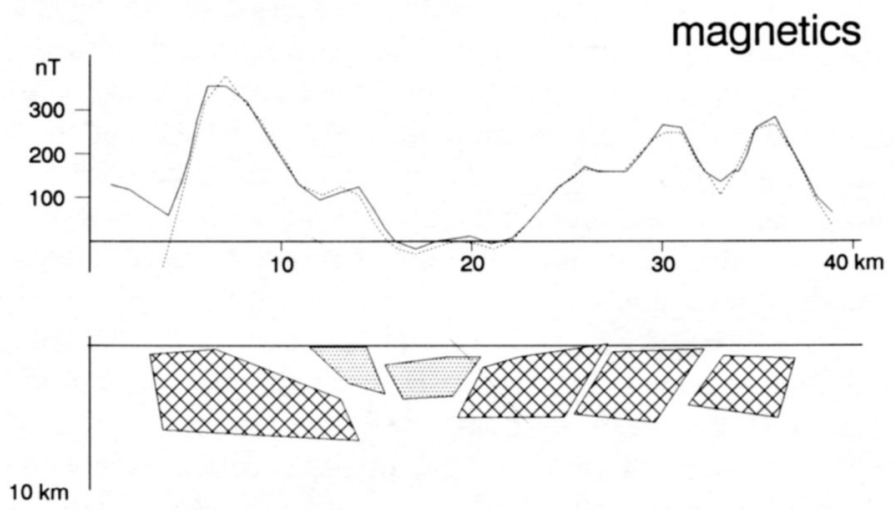

Fig. 7. Modelled data for profile EE-FF. Hatched patterns indicate magnetic bodies with magnetizations in $10^{-3} \mathrm{MKS}$ units as follows:

Range 2.1-2.7 Range 1.2-1.7

$0.8 \square 72$

Dark solid lines outline the bodies used in calculating gravity effect. On the profiles, solid lines represent the observed data and dashed lines are the calculated effect for the bodies depicted.

Standard 2 1/2-D forward modelling algorithms were used in the modelling. In this method the causative bodies are considered to have a cross section in the plane of the profile, which continues for a finite distance perpendicular to that plane. The distances to the ends of the bodies perpendicular to the profile can be different for each end, i.e., the profile does not have to transect the centre of the body. Ideally, profiles modelled in this way should be extracted perpendicular to the strike of the anomaly patterns on the map. An inspection of the orientation of the profiles on the map (Fig. 2) demonstrates that only profile EE-FF is well oriented for such modelling; the modelled bodies on this profile can then be considered as indicative of the true geometry in the subsurface. The position of profile AA-BB was constrained by the road access available to conduct the gravity survey; the modelled bodies provide information on the general geometry and depth extent of the causative bodies.

The model developed for profile AA-BB (Fig. 6) from the combined gravity and magnetic data indicates that the magnetic anomaly pattern on the northwest is explained by a vertical truncation on the west side of the block responsible for the edge anomaly. Immediately inside this block there must be another, thinner, inward dipping block of lower magnetization. In the central portion there must be two additional blocks of lower magnetization, dipping in opposite directions relative to the profile direction. The southeastern end of the profile is modelled with an inward-dipping block having the lowest magnetization. The gravity model, developed using material having a density contrast of +0.20 $\mathrm{g} \mathrm{cm}^{-3}$, suggests a gabbroic body thickening inward and reaching a maximum thickness of $5 \mathrm{~km}$ at $30 \mathrm{~km}$ along the 
profile. A change in slope in the gravity anomaly occurs at 27 $\mathrm{km}$, between the two magnetic sources having reverse dip. This position also coincides with intersection of the shadow zone from $5440 \mathrm{~N}, 638 \mathrm{E}$ to $5410 \mathrm{~N}, 625 \mathrm{E}$ with the profile. The sample density data and the published geological mapping indicate that this is approximately the western edge of the granite on the profile; these data, together with the geochemical data, suggest the presence of granite to the east of this; hence the granite is modelled as a thin veneer underlain by denser gabbro.

The primary magnetic profile across the complex, EEFF, indicates again that the western edge of the block associated with the western anomaly pattern is near vertical to slightly inward-dipping, and the top of the pattern is inwarddipping, similar to the results for profile AA-BB. The magnetization is also similar to that for the same block on AA$B B$. The next block inward of this also dips inward, followed by a block of lower magnetization which is essentially horizontal. The three blocks used to model the eastern portion of the complex are all inward-dipping and of higher magnetization. Again, the direction of dip changes across the intersection of the linear from $5440 \mathrm{~N}, 638 \mathrm{E}$ to $5410 \mathrm{~N}, 625 \mathrm{E}$. It should be noted that the modelled profile has an acute angle intersection with the interior anomalies, and therefore the dip determined is not the true dip. Nevertheless, the model provides significant evidence of an inward dip to the sources of the anomaly pattern in the complex anomaly area.

On both profiles the general geometry of the models is similar, as are the block magnetizations. The western bodies are more magnetic than those in the centre, suggesting that a subsequent process may have altered the magnetization of the central bodies. The models also suggest the influence of some process at the intersection of the linear magnetic pattern with the profiles.

\section{Geological Interpretation}

The combined geophysical, geochemical and geological data indicate that the subsurface configuration of the Mount Peyton complex is more complicated than proposed by earlier interpreters (Weaver, 1967; Strong and Dupuy, 1982), but is in general of the same geometrical form. The presence of the positive magnetic anomaly around the edges of the complex, together with the elevated nickel and copper values immediately outside in the drainage channels, the measured susceptibility for the gabbro and the inferred elevated magnetization in the models indicate that these inward dipping bodies associated with the edges are probably gabbro, especially as the gravity modelling suggests that they have relatively high density.

The modelling suggests that the granite is relatively thin; the geochemical data are consistent with a larger area underlain by granite (Fig. 1). The limited outcrop data place some constraints on the location of the northern portion of the boundary.

Dating (Reynolds et al., 1981) indicates that the gabbro causing the edge magnetic anomalies was emplaced first at
-420 Ma. The magnetic signatures indicate that the gabbro could have been emplaced as a sheet, thereby explaining the near vertical outer edges. One possible scenario is that the emplaced gabbro sheet was subsequently broken up by northeast-trending faults, typified by the two northeast-trending offset features identified. This disturbance may also have been responsible for some east-west offset, now visible in the patterns at $5410 \mathrm{~N}$. The granite may have been intruded at 390 Ma along these younger faults. The granite covered the eastern portion of the complex as indicated by the geochemical data, especially the uranium values. It should be noted that the thickest granite coincides with the highest uranium values. The relative proportions of granite and gabbro in the complex are similar to those suggested by Strong (1979) and Strong and Dupuy (1982), i.e., the volume extent of the granite is much less than the proportion of granite outcrop. The faulting may have been responsible for some tilting of gabbro blocks in the interior of the complex, a mechanism comparable with that suggested by Miller and Tuach (1989) for the Ackley batholith in southern Newfoundland, and also one which could have resulted in the dip reversal seen in the modelling as occurring at a position where the linear features identified from the shaded relief cross the modelled profiles. The inferred lower susceptibility of the central gabbro blocks, deduced from the modelling, is consistent with remagnetization of these blocks due to effects of the granite. The sequence proposed could also explain the paleomagnetic data (Lapointe, 1979) and the resetting of the Ar data as reported in Strong (1979).

\section{Conclusion}

The configuration of gabbroic and granitic units in the Mount Peyton batholith has been elucidated by combined geophysical, geochemical and geological interpretation. The general conclusions of older studies relating to the overall geometric configuration have been corroborated and more detail has been deduced, which provides further evidence for two significant episodes of magma emplacement and at least one episode of faulting. The granitic unit has been interpreted to occupy a larger area than that indicated by the earlier studies.

The study provides further evidence for the association of granites in Newfoundland with episodes of faulting. It also demonstrates the importance of considering combined geological, geophysical and geochemical data in studying the setting of major plutonic complexes.

\section{ACKnowledgements}

John Hayes and Gerry Kilfoil of the Newfoundland Department of Mines and Energy provided the geochemical and magnetic data on which this paper is based. R. Wiseman of Memorial University assisted with extensive revision of the models. The paper is a summary of a B.Sc. thesis submitted by one author (SAMT) to Memorial University. The field phase was conducted through funding by an NSERC grant to 
HGM. The manuscript benefited from the comments of two journal reviewers.

Bell, K., Blenkinsop, J., and Strono, D.F. 1977. The geochronology of some granite bearing rocks from eastern Newfoundland and its bearing on Appalachian evolution. Canadian Journal of Earth Sciences, 14, pp. 456-476.

BLACK WOOD, R.F. 1982. Geology of the Gander Lake (2D/15) and Gander River (2E/2) area. Report 82-4, Mineral Development Division, Newfoundland Department of Mines and Energy, St. John's, Newfoundand, 56 p.

Colman-SAdD, S.P., HaYes, J.P., and Knioht, I. 1990 Geology of the Island of Newfoundland. Map 90-01, Geological Survey Branch, Newfoundland Department of Mines and Energy. St. John's, Newfoundland.

DA VENPORT, P.H. and Nowlan, L.M. 1988. Gold and associated elements in the Botwood (NTS 2E) map area. Newfoundland Department of Mines, Mineral Development Division, Open File $2 \mathrm{E} / 563$.

Davenport, P.H., Nowlan, L.M., and Hayes, J.P. 1988. Gold and associated elements in the Gander Lake (NTS 2D) map area. Newfoundland Department of Mines, Mineral Development Division, Open File 2D/175.

LAPointe, P.L. 1979. Paleomagnetism and orogenic history of the Botwood Group and Mount Peyton batholith, central mobile belt, Newfoundland. Canadian Journal of Earth Sciences, 16, pp. 866-876.

LeAKE, B.E. 1990. Granite magmas: their sources, initiation and consequences of emplacement. Journal of the Geological Society, London, 147, pp. 579-589.

Miller, H.G. 1970. A gravity survey of eastem Notre Dame Bay, Newfoundland. Unpublished M.Sc. thesis, Memorial University of Newfoundland, $83 \mathrm{p}$.

1976. A magnetic model of the Budgell Harbour Stock, Newfoundland. Canadian Journal of Earth Sciences, 3, pp. 231-236.

1988. Geophysical studies of the Ackley intrusive suite and the northeastern Gander zone, New foundland. Geological Survey of Newfoundland, Newfoundland Department of Mines and Energy, Report 88-3, 44 p.

Miller, H.G. and Pittman, D.A. 1982. Geophysical constraints on the thickness of the Holyrood Pluton, Avalon Peninsula, Newfoundland. Maritime Sediments and Atlantic Geology, 18, pp. 75-82.

Miller, H.G. and TUACH, J. 1989. Gravity and magnetic signa- tures of the Ackley Granite Suite, southeastern Newfoundland: implications for magma emplacement. Canadian Journal of Earth Sciences, 26, pp. 2697-2709.

O'Reonn, R. 1986. A magnetic model for the Jurassic Dildo Pond Stock north-central Newfoundland. Unpublished B.Sc. thesis dissertation, Memorial University of Newfoundland, $34 \mathrm{p}$.

Reynolds, P.H., Taylor, K.A., and Moroan, W.R. 1981. ${ }^{40} \mathrm{Ar} /$ ${ }^{39} \mathrm{Ar}$ ages from the Botwood-Mount Peyton region, Newfoundland: possible paleomagnetic implications. Canadian Journal of Earth Sciences, 18, pp. 1850-1855.

Seguin, M.K. 1982a. Geophysics of the Canadian Appalachians. Tectonophysics, 81, pp. 1-50.

1982b. Emplacement of the Monteregian Hills of Quebec; Geophysical evidence. Tectonophysics, 86, pp. 305-317.

Strono, D.F. 1979. The Mount Peyton batholith, Central Newfoundland, a bimodal calc-alkaline suite. Journal of Petrology, 20, pp. 119-138.

Strono, D.F. and DUPUY, C. 1982. Rare earth elements in the bimodal Mount Peyton batholith: evidence of the crustal anatexis by mantle-derived magma. Canadian Journal of Earth Sciences, 19, pp. 308-315.

Strono, D.F., Dickson, W.L., O'Driscoll, C.F., and Kean, B.F. 1974. Geochemistry of eastern Newfoundland granitoid rocks. Report 74-3, Mineral Development Division, Newfoundland Department of Mines and Energy, $140 \mathrm{p}$.

SweENEY, J.F. 1976. Subsurface distribution of granitic rocks, south-central Maine. Geological Society of America Bulletin. 87, pp. 241-249.

Thomas, M.D. and Willis, C. 1989. Gravity modelling of the Saint George Batholith and adjacent terrane within the Appalachian Orogen, southem New Brunswick. Canadian Journal of Earth Sciences, 26, pp. 561-576.

WeA Ver, D.F. 1967. A geological interpretation of the Bouguer anomaly field of Newfoundland. Publication of the Dominion Observatory, Ottawa, xxxv, pp. 223-251.

Williams, H. and Ha wORTH, R.T. 1984a. Magnetic anomaly map of Atlantic Canada. Memorial University of Newfoundland, Map 5.

1984b. Bouguer gravity anomaly map of Atlantic Canada. Memorial University of Newfoundland, Map 6.

Williams, H., Dickson, W.L., Currie, L., Hayes, J.P., and TUACH, J. 1989. Preliminary report on a classification of Newfoundland granitic rocks and their relations to tectonostratigraphic zones and lower crustal blocks. In Current Research, Part B, Geological Survey of Canada, pp. 47-53. 